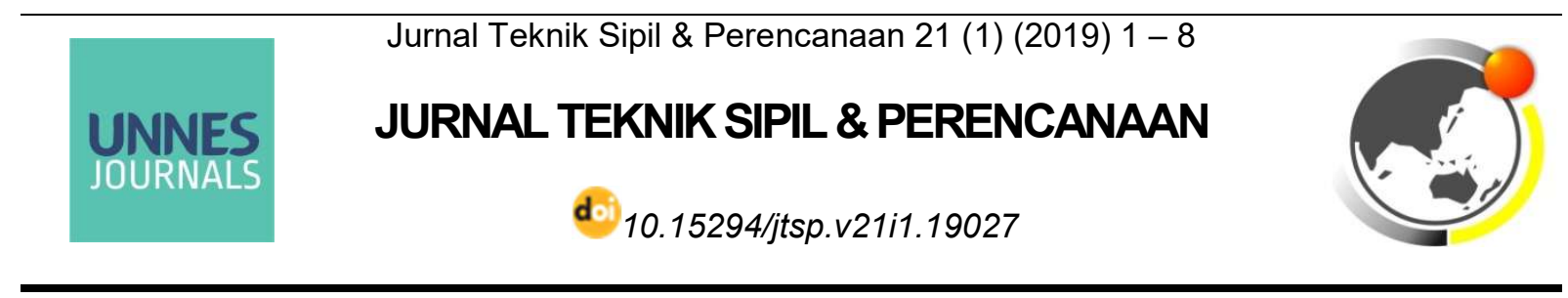

\title{
The Implication of Studentification to Community's Physical and Social Economic aspects in Tembalang Higher Education Area
}

\author{
Santy Paulla Dewi ${ }^{1, a)}$ and Novia Sari Ristianti ${ }^{1, b)}$ \\ ${ }^{I}$ Department of Urban and Regional Planning, Diponegoro University, Semarang, Indonesia \\ a) Corresponding author: santy.paulla.dewi@pwk.undip.ac.id \\ b) novia.sari@pwk.undip.ac.id
}

\begin{abstract}
Studentification is a neighbourhood changes caused by the students' presence in the permanent settlement then influence the area; students accomodation supply and community's social economic aspects. This research revealed the influence of studentification in Tembalang higher education area to the physical and social economic aspects. Qualitative research method was used to explain more about the studentification influence and the Tembalang development trend. Interview conducted to some key figures in the community such as Lurah, community leaders, and students to find out their perception regarding the neighbourhood transformation. Based on analysis, it showed that studentification emerged since the Pleburan campus moved to Tembalang campus which students accomodation demand increased significantly. Moreover, the studentification influences seen from the increasing of land price, land use conversion, and students' life style that affected the community's job-shifting. However, the development of Tembalang higher education area still on the track based on the guidance and spatial pattern structure recommendation of Semarang Spatial Plan 2011-2030.
\end{abstract}

\section{INTRODUCTION}

Universtas Diponegoro (Undip) is as one of the advance universities in Indonesia that continues to grow. This is indicated by an increase in the number of students from year to year; the number of students in 2018 was 43,157. The increase in the number of students has implications for the increasing demand for housing for students as well as facilities and infrastructure supporting educational activities. In the end, the development of Undip greatly affected the surrounding area, namely in the higher education area of Tembalang. Campus, in this case is Undip, the main activity of education is considered to be able to drive economic activity as a follow-up activity and become a generator of economic growth in the surrounding area [1]. This began to be very visible after the relocation of the Undip Pleburan campus to the Tembalang campus in 2010 where as many as 3,000 students also moved and resided in Tembalang. This figure has not been added to the number of Undip students each year which reaches 10,000 per year [7]. In the end, residential needs for students increased very meaningfully. This is in line with improving economic facilities to support student life. The economic development in Tembalang is indicated by the emergence of economic facilities such as trade and supporting services for educational activities, such as food stalls, photocopying services, laundry, and others. In the end, conversion of agricultural land and land use change is inevitable; from agricultural land and houses to boarding houses and infrastructure and trade services and services [9]. Furthermore, the competition to get land is increasing every year which causes land prices to increase. The price of land in Tembalang in 2018 reaches IDR 3,500,000 to 5,000,000 per m2 [8]. Student residence rental fees and land taxes also increased.

Increasing demand for land in the Tembalang area led to the increasing prices of the land. Therefore, most of the people in Tembalang community sell their land [9]. The process of displacing the indigenous Tembalang people began to occur and signaled the occurrence of studentification. Other characteristics of studentification are the physical changes in the area, changes in the composition of the population, and the development of economic activity [2]. Studentification is defined as a change or transformation of the area due to the construction of student 
accommodation that occurs around the higher education area [10]. Furthermore [11] also states that the studentification process that occurs is strongly influenced by the development of educational activities, such as the construction of new campuses and an increase in the number of students and all characteristics influence the life order in society. This study is a series of studentification studies in Tembalang's higher education area and follow-up from previous studies regarding the process of studentification in the Tembalang area. The aim of this paper is to analyze the influence of studentification in Tembalang's higher education area from socio-economic and physical aspects. The effect of studentification begins by analyzing the socio-economic and physical changes that occur by comparing land use and land use before moving the Pleburan campus to Tembalang (in 2010) with existing conditions. Furthermore, it was also analyzed regarding the trends in the development of land use and land use in Tembalang and comparing its suitability with the Semarang's Spatial Planning and Detail Spatial Planning.

\section{STUDENTIFICATION AND GENTRIFICATION}

Studentification is one mutation of gentrification, which has several similarities and differences [11]. The equation between gentrification and studentification refers to changes in the area caused by a resultant such as development activities or regional improvements that make the physical area change very significantly from the previous conditions such as increasing land prices and taxes, and regional economic growth. The difference between gentrification and studentification can be viewed from the location of occurrence, the time period (the process), and its influence [12]. First, from the location of occurrence, gentrification generally occurs in the downtown area with high economic value with the low quality of the environment. On the other hand, studentification occurs in the area of higher education which does not necessarily have a downtown area. Second, gentrification occurs gradually; slowly, while studentification occurs relatively faster because it is influenced by the length of time students reside in an area of 4-5 years on average. Third, from its influence, on the economic aspect, new types of work began to emerge which had a different variety in the region which was centrified and which had studentification. In the socio-cultural aspects, a difference is also seen. Gentrification is characterized by changes in social relations of the community. On the other hand, the studentification is indicated by the influence of students' lifestyles that tend to be student-oriented lifestyle.

The influence of gentrification has been more on the negative side, where there are low income groups who are then eliminated from areas that they have been cultivating for several years. This is due to an increase in living standards and taxes. In the end the remaining choice is to sell his house and move to another location that is more economically affordable [3]. However, the resultant activity that triggers changes in different regions and the character of students with shorter stays and financially still depends on parents provides different colors and influences on the community and the area around student housing. Therefore, research on studentification is expected to contribute to the study of gentrification in order to obtain a comprehensive picture.

Students as immigrants (studentifiers) become key actors that influence the regional economic structure, such as the level of investment for both student occupancy and trade and services, types of economic activity. Furthermore, this affects the physical aspects of the area, in this case the increasing development of new houses for student housing and for trade and services which ultimately changes the physical face of the area [4]. In addition to economic aspects and physical aspects, the existence of students also influences population configuration and lifestyle changes [5]. The socio-economic background of students who generally come from families with middle to high economic levels is very different from the character of the Tembalang community, most of them are classified as middle to low income groups. In the end, this increased the economic standard in the Tembalang area. The difference in economic characteristics between students and the Tembalang community is also one indication of studentification, which is generally found in middle-lower class neighborhoods which then turn into student housing with better and more modern physical forms [13].

\section{RESEARCH METHODOLOGY}

The justification of location selection in Tembalang is due to several considerations, one of which is the direction of land use where according to the Semarang City planning (RT RW) in 2011-2030. It is stated that Tembalang was directed as a higher education area. This is indicated by the presence of several universities in Tembalang; Undip, Polines, Unpand, and Stikes. Another justification is because the development of Undip is one of the significant universities in Indonesia. In addition, the physical changes in the Tembalang area and land conversion are very clear, which suggests that there is studentification.

This study used qualitative methods, with the variables used in this study were social aspects, such as students' origin, perceptions and preferences of students regarding the characteristics of occupancy, and relations with local communities and boarding house owners. Economic variables were viewed from the people's livelihoods, income 
and expenses of both the community and students. Moreover, physical variables are seen from the physical changes in the area, and use of land, and trends.

Interviews were conducted with six informants who were considered to be aware of the development of the Tembalang area, such as the Head of Sub district and Sub-District Head of Tembalang, the Tembalang community both who were still stationed at Tembalang and who had moved, and students. The interview process was carried out by using the snowball sampling method with key informants, Head of Tembalang Village. Some of the questions raised in the interview process were emphasized more on the development of Tembalang before 2010 and now, community characteristics, community social relations, policies related to land use and utilization, and provision of shelter for students. The field observations were carried out to find out and verify data on land use and utilization, physical conditions of community homes, physical conditions of students' housing, and existing economic facilities. On the other hand, secondary data were more pressing on the monographic data and Tembalang in numbers obtained from the District and Tembalang village, and Central Bureau of Statistics, and the Semarang City planning from Bappeda.

The descriptive qualitative and map overlay were used to analyze. Qualitative descriptive was used to describe the characteristics of the community and students, perceptions and preferences of the community and students related to occupancy, social relations between the community and between the community and students, to lifestyle changes, and economic preferences (such as job choice and utilization of economic facilities). Although the technique used is descriptive qualitative, there are still some data in the form of numbers illustrated in diagrams and tables such as population and number of students. The diagrams and tables were used to facilitate reading the results. The overlaying the map was used to find out the changes in existing conditions both from land use and from utilization compared to 2010. In addition, map overlays were also conducted to determine the trends in physical development of the Tembalang higher education area compared to land use referral maps from the spatial plans. From this process, it is known that the physical development of the Tembalang area is still in accordance with the government's direction. In addition, the direction of the physical development of the area can be anticipated in the future. Determining the extent of the influence of studentification on the community and the area around Tembalang required comparative qualitative analysis that compared physical conditions in 2010 and 2018, the distribution of students' occupancy, students' preferences in choosing occupancy, community perceptions and the reasons they moved and settled in Tembalang.

\section{RESULT AND DISCUSSION}

\section{Process of Studentification In Tembalang}

Before discussing the effect of studentification on the surrounding area, the process of studentification itself was reviewed. As previously stated, this study is a follow-up of previous studies that have discussed the process of studentification in the higher education area of Tembalang. Therefore, a review of the studentification process was carried out to find a common thread with the study of the effect of studentification.

Since the transfer of the Undip Pleburan campus to the Tembalang campus, the physical development of the Tembalang area underwent a significant change. This is due to the increase in student occupancy and economic facilities provided along with the increase in the number of students. Therefore, the identified studentification process began to occur during the transfer of the campus or starting in 2010. Related to student occupancy, there are several types, including housing with multiple occupations, PBSA (purposed built student accommodation), and occupancy provided by community personally. In this case, the HMO is defined as a student residence or boarding house that is still integrated with the property owner in a unit of building, which sometimes functions as a food stall or other place of business. These HMOs are often found in the middle of community settlement areas and are owned by indigenous Tembalang residents. On the other hand, PBSA in this case is dormitory provided by Undip and several student apartments provided by private developers. Both are classified as PBSA because indeed the construction of the two types of housing are intended for students so that starting from the room area and facilities provided adjust the needs of students. The rent provided by individuals is owned by people outside Tembalang who buy land or houses of the Tembalang community and then rebuild with different physical forms. The community of remote verification information in general is low-class economic groups (working-class groups). They have also presented a broker in providing housing for students with inadequate quality. Most of them depend their lives on rent to meet their daily needs. As a result, they do not have enough savings to care for boarding houses. On the other hand, students as tenants are not responsible for the maintenance costs of boarding houses, so they tend not to maintain the property. In the end, the boarding houses provided by the indigenous people became poorly maintained and became increasingly less attractive to students [12]. If this condition continues, then they cannot continue and sell their house.

Further, the stages of studentification in the higher education area of Tembalang are illustrated on the figure 1. The division of these stages was based on the time before the transfer of the Pleburan campus to Tembalang, 
after the transfer of the campus, and now. The influence of studentification on the community and the surrounding area can be seen from several aspects, namely the price of land, the number and composition of the population, and the social aspects (lifestyle of students and society) [9].

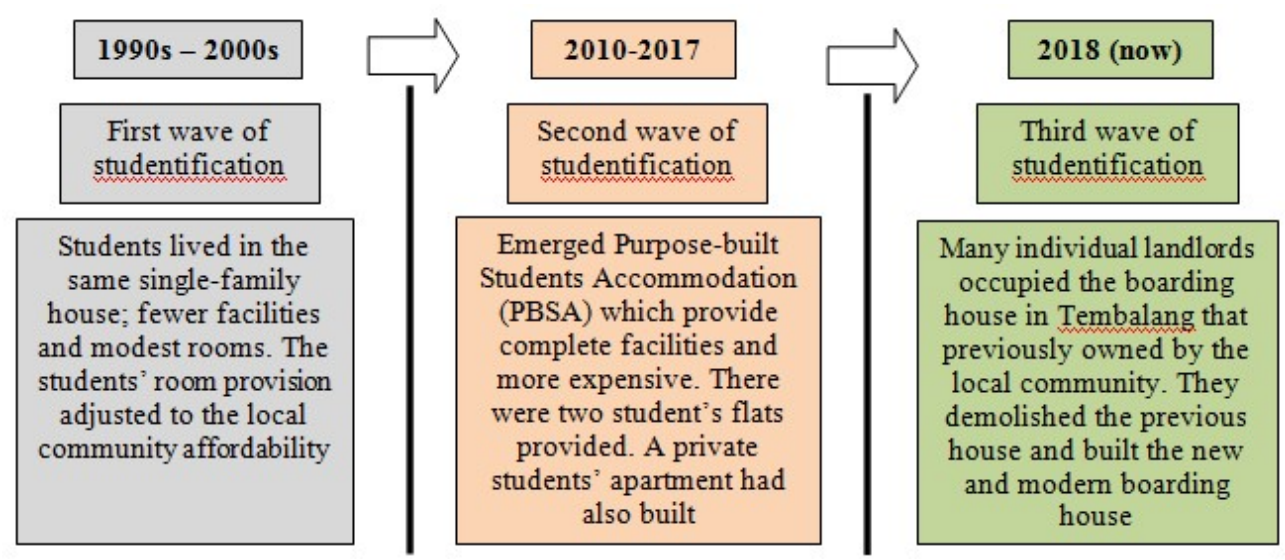

FIGURE 1. The Studentification Process in Tembalang 1990-2018 [9]

\section{The Implication of Studentification on Land Prices}

One of the influences of the studentification process can be seen from the increase in land prices. The increasing demand for student housing, the demand for land for economic activities (trade and service facilities), and the increasing interest of the community outside Tembalang for investment are factors that cause an increase in land prices. Based on research conducted by [6] stated that the highest increase in land prices in the Tembalang higher education area began from Rp 829,000 - Rp 3,235,000 per $\mathrm{m} 2$ (in 2013). The highest land prices are in locations along the main road, have good access, and are close to economic facilities; around Sirajudin Street, Banjarsari Street, and Tembalang Selatan Street.

In addition, it was also mentioned that the biggest change in land use (50\%) in the Tembalang area was from dry fields to housing and changes from rice fields to housing $(21.78 \%)$. While the growth of trade facilities and services exist along the main road and follows housing growth. The justification for changes in land use and utilization is due to an increase in land tax. Productive activities (both student occupancy and trade and services) are one of the rational choices for the community to be able to benefit while paying taxes. Some of the buildings that initially had a front yard or backyard finally chose to use it as a business area (built as student housing or food stalls). Many buildings that eventually made the front yard of his house as a place of business and increased KDB Tembalang District. Therefore, many buildings no longer have building border lines.

"Yes, the price (land) is now expensive, it seems impossible to buy more land just to make a new boarding room, I stand by what is there. Incidentally, beside my house there are still a few vacant lots "

(Boarding House Owner)

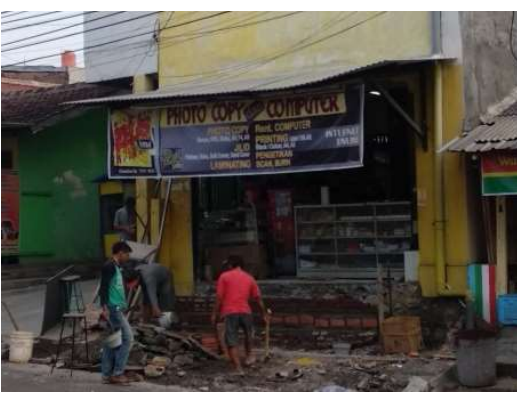

(a)

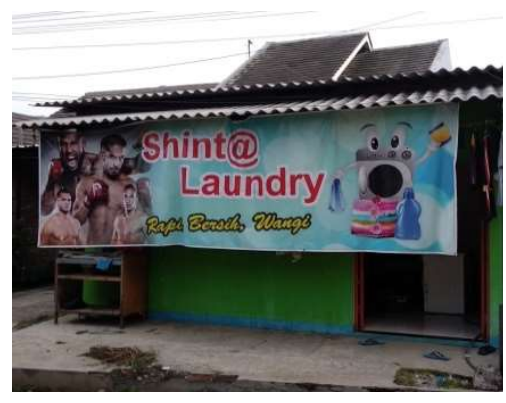

(b)

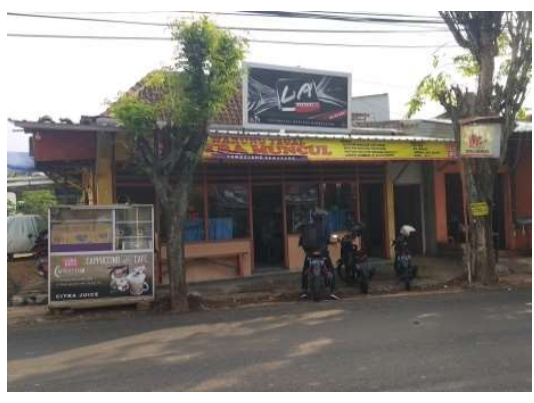

(c)

FIGURE 2. Trade and Service Business (supporting educational activities) in the Tembalang Area

In addition to maximizing land with horizontal development direction, some communities also add the height of the building so that they can maximize it without having to add land. This can be seen through the number of 
student residential buildings that add to the floor of the building. There are also buildings such as shop houses. The first floor is used for shops or stalls while the second floor of the building is used as boarding house.

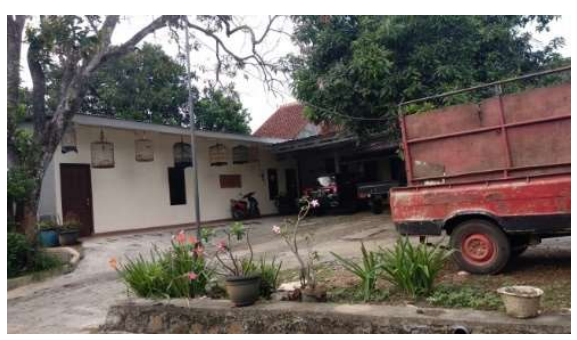

(a)

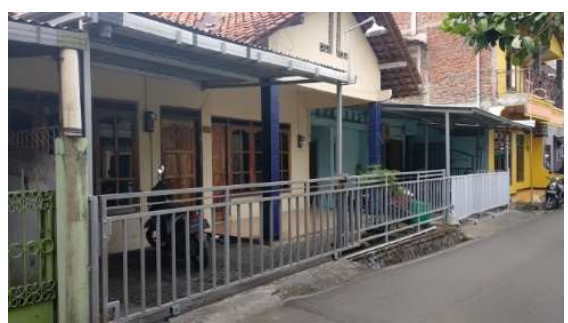

(b)

FIGURE 3. Student Boarding House Provided By The Local Community's Front Yard (HMO's Type)

Unlike the student residential buildings built by the local community of Tembalang, student housing built by investors has taken into account many things before starting to build a boarding house for business. If the boarding house belongs to a local community. It is usually built in stages, the boarding house built by investors is more planned and usually the number of floors needed is calculated with an estimated number of students who continue to grow. Therefore, boarding houses by investors will have a modern design and more complete facilities.

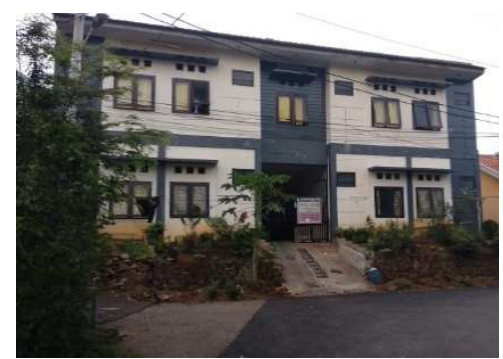

(a)

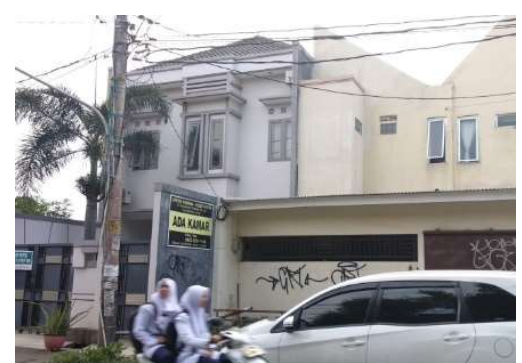

(b)

FIGURE 4. Students' Boarding House Provided By The Investor (PBSA's Type)

\section{The Implication of Studentification on The Students Number}

Based on the data, the number of Undip students increases every year. The increase in the number of students is also due to the increase in services and development of Undip. Like the Undip Tembalang campus which is currently not only for undergraduate study program students, but also diploma, master, and doctoral degrees. Nevertheless, there are still students who choose not to live in the Tembalang area for various reasons, such as students from within the city. Most students from within the city do not live in the Tembalang sub-district. In addition, master and doctoral study program students also prioritize residential facilities because in general, master and doctoral study students already have family and worked. The choice of residence in Tembalang by undergraduate and diploma students is usually caused by ease of accessibility from residential to campus. This will be far easier and cheaper than having to live in an area far from campus. In addition, although not all students live in Tembalang, the attraction that Undip has between $8 \mathrm{am}$ and $5 \mathrm{pm}$ can be said to be quite high. This becomes an opportunity for business owners (stalls, food stalls, printing sites, etc.) to get more consumers.

\section{The Implication of Studentification on Students Life Style}

Students have a different lifestyle than the local population. With the end of academic activities in Undip at $17.00 \mathrm{pm}$, few students finally chose to use the cafes in Tembalang to conduct academic related activities. In addition, there are also students who are mostly residents aged 19 to 25 who use cafes as a place to gather and socialize. Therefore, many investors choose to take advantage of the students' lifestyle as the reason for their business. Many cafes are built which are open until midnight, until 3 o'clock in the morning or 24 hours. In addition, there is also the latest clothing stores built on Tembalang. The market of the store is students or young residents. This can be seen from the type of clothing sold.

"Well, now students prefer cafes, modern snacks, good places" 
Before the removal of Undip in Tembalang District, many of the original residents were traders in the market, housewives, unemployed, and even employees. They assess the existence of students as an opportunity to develop their business and get greater profits. Therefore, they choose businesses such as food stalls, laundry, printing sites, and boarding houses. These businesses are considered beneficial because they can meet the needs of students in Tembalang. The community uses it by building boarding houses as a provision for student housing needs. Besides that, the number of food stalls is also often increasing and even has developed by providing more modern concepts and the interest of students. Printing and laundry facilities are also one of the many types of businesses that have developed in the Tembalang education area.

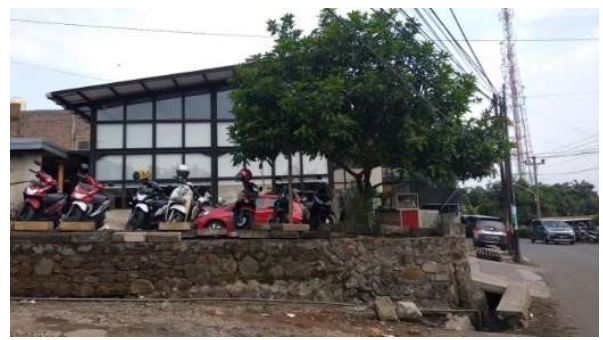

(a)

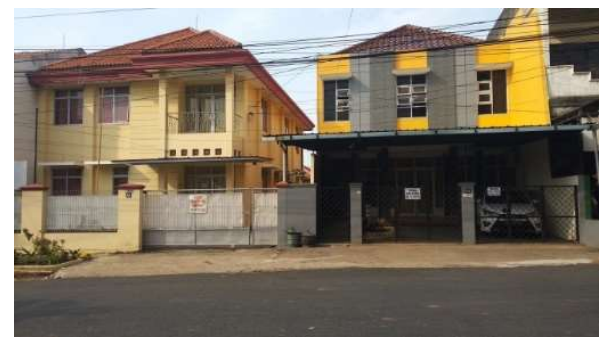

(b)

FIGURE 5. (a) 24 hours cafe that is always crowded with students (b) 24 hours of Luxury boarding house

It can be said also that the student's lifestyle influences socio-economic aspects, in this case is the type of work that appears in the Tembalang education area. The community seizes this opportunity by changing jobs or from the original housewife to being a trader. In fact, the income received from the food and laundry stalls business that was originally as an additional job and a side job is actually the amount is greater than the main job of the husband (as a driver and laborer).

\section{Development Trends of Students' Boarding House}

Student occupancy continues to grow until now, both types; PBSA occupancy type and modern boarding house provided by the community individually (private), as well as from the number that continues to increase. Ultimately, this makes changes to land use and use. However, based on the Semarang City planning 2011-2030, the development of student housing and all economic facilities that emerge is still in accordance with the direction of the policy. In accordance with the city planning, Tembalang is indeed recommended as a higher education area. Land use suitability analysis was performed by comparing between existing land use maps with land use land maps based on the city planning. Differences that can be identified are more on the existence of residential areas that should be the higher education area of Tembalang. This is seen from the Jurang Blimbing village which is in the middle of the Undip campus where it is currently growing. It is marked by the increasing number of boarding houses being built and the increasing number of food stalls and other economic facilities, which not only provide for students but also families of patients treated at Undip Hospital (RSND). The location of the Jurang Blimbing village which is adjacent to the RSND has made many people open food stalls in the region.

Based on the results of identification, it was found that $89.02 \%$ (or an area of $344.27 \mathrm{ha}$ ) of land use was appropriate; where the appropriate land allotment is for education areas, settlements, and offices. While $10.98 \%$ (or an area of $42.46 \mathrm{ha}$ ) is not suitable, especially the function of the area in the plan as an education area, but in reality it is a residential area. However, for the trend of development of student housing will be more to the south of Tembalang, in this case towards the Kramas Village. In addition to the wide availability of open land, also based on the spatial pattern structure of the city planning, this village has a function as a residential area; currently still in the form of open land and moor - land. 


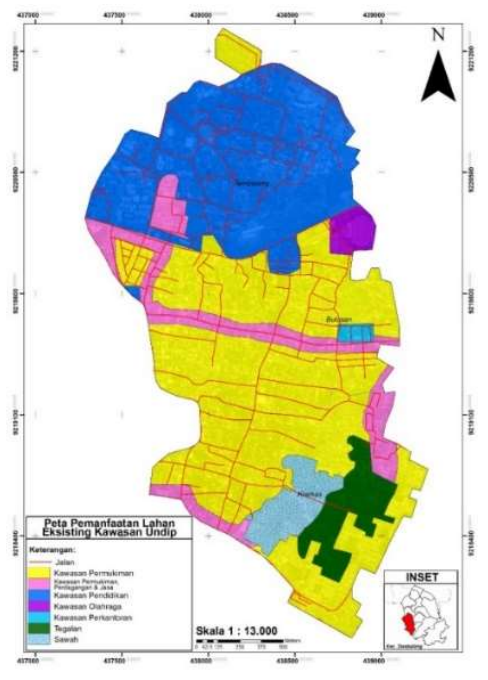

(a)

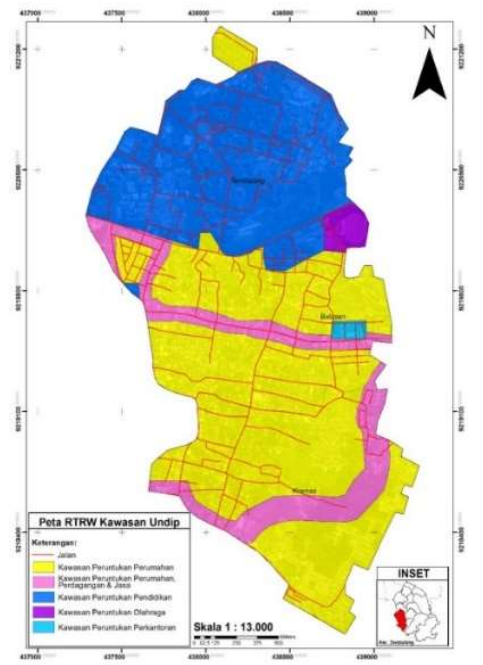

(b)

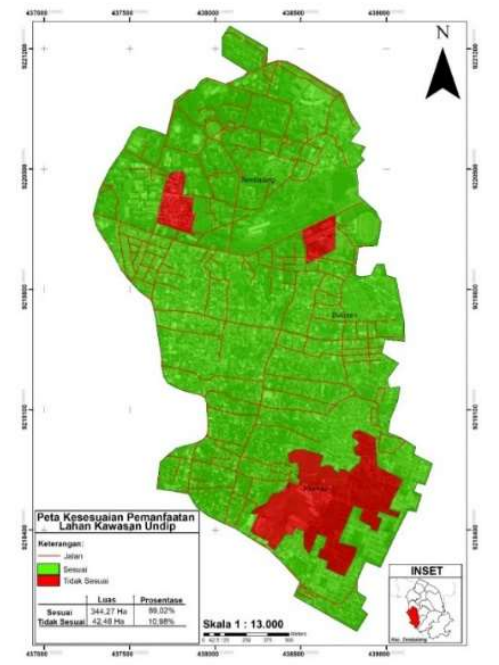

(c)

FIGURE 6. (a) Existing Land Use (b) Land Use Planning (c) Suitability of Land Use [14]

\section{CONCLUSION}

Studentification is a transformation of the settlement environment that occurs in the education area and cannot be avoided. The study at Tembalang is influenced by the development and development of Undip; concentration of educational activities from the one originally in Pleburandistrict to Tembalang District also the increase in the number of students every year. Increased residential choices for students make the demand for land and student housing in Tembalang District also increase. It is not only replaces the local community, but also increases land prices, land and building taxes, and living standards. The influence of studentification can also be seen from changes in lifestyle and livelihoods of people affected by the lifestyle of students. Studentification is still ongoing. However, the use of existing land is still in accordance with the directions of the spatial plan structure. The tendency of the construction of student housing is more towards the Kramas Village with consideration of land availability and accessibility.

Based on the results of the study, there are a number of suggestions in facing the transformation of the Tembalang educational area. This proposal is intended for those who have a role and authority in developing the Tembalang university area. Unplanned growth in the Tembalang area is one of the factors causing the spread of residential areas for students that cannot be controlled. This growth continues until the occurrence of studentification causes local people to move to peripheral areas and causes urban sprawl. The construction of student housing also causes Tembalang's Building Coverage and Floor Area Ratio values to increase and increase regional density. Therefore, comprehensive management is needed from the government, especially in facing changes in the Tembalang area which will continue to have new students who will stay temporarily. This is a challenge for the Tembalang education area considering the number of students continues to grow from year to year. The presence of investors who are mostly not domiciled in the Tembalang area is one of the factors decreasing public participation. This can be seen from the low awareness of the environment. This problem is compounded by the absence of data on boarding houses owned by indigenous people and investors. Therefore, cooperation between local government officials is needed (applied at the village, RT and RW levels).

\section{REFERENCES}

[1] N. S. Foote, "Beyond studentification in United States College Towns: Neighborhood change in the knowledge nodes, 1980--2010," Environ. Plan. A, vol. 49, no. 6, pp. 1341-1360, 2017.

[2] R. J. Johnston, D. Gregory, G. Pratt, and M. Watts, The Dictionary of Human Geography. ed. Oxford, UK: Blackwell Publishers, 2000.

[3] S. P. Dewi, "Gentrification and the Vulnerability of Betawi Community," in IOP Conference Series: Earth and Environmental Science, 2018, vol. 158, no. 1, p. 12009.

[4] C. W. Ause, "Black and Green: How Disinvestment, Displacement and Segregation Created the Conditions For Eco-Gentrification in Portland's Albina District, 1940-2015," Portland State University, 2016.

[5] J. DeSena, The Gentrification and Inequality in Brooklyn: New Kids on the Block. United Kingdom: 
Lexington Books, 2009.

[6] R. Aminullah, A. Suprayogi, and A. Sukmono, “APLIKASI PGROUTING UNTUK PENENTUAN RUTE ALTERNATIF MENUJU WISATA BATIK DI KOTA PEKALONGAN BERBASIS WEBGIS," J. Geod. Undip, vol. 7, no. 1, pp. 109-119, 2018.

[7] www.undip.ac.id

[8] www.urbanindo.com

[9] S. P. Dewi, N.S. Ristianti, "Studentification Process in Tembalang Higher Education Area," in IOP Conference Series: Earth and Environmental Science, 2019

[10] Monroy, P. (2017). Shifting perspectives on "studentification": A multi-disciplinary approach, (April), 0-14. https://doi.org/10.13140/RG.2.2.19080.62721

[11] Smith, N. (1996). The Revanchist City. The New Urban Frontier: Gentrification and the revanchist city. https://doi.org/10.1177/030913259702100327

[12] Moos, M., Revington, N., Wilkin, T., \& Andrey, J. (2018). The knowledge economy city: Gentrification, studentification and youthification, and their connections to universities. Urban Studies. https://doi.org/10.1177/0042098017745235

[13] Smith, N. (2005). The new urban frontier: Gentrification and the revanchist city. Routledge.

[14] RTRW Kota Semarang Tahun 2011-2030 